\title{
Włączanie i wyłączanie uczniów ze specjalnymi potrzebami edukacyjnymi z ogólnego nurtu działań edukacyjnych - rozwiązania praktyczne w kontekście przepisów prawa oświatowego na przykładzie miasta Gdańska i nie tylko
}

Autor w swoim artykule definiuje uczniów ze specjalnymi potrzebami edukacyjnymi i edukację inkluzyjną. Przedstawia możliwości wspierania uczniów ze specjalnymi potrzebami edukacyjnymi w szkole ogólnodostępnej, ze szczególnym uwzględnieniem ich włączania w grupę rówieśniczą i wyłączania z niej. Omawia różne możliwości rozwiązań wynikające z przepisów prawa oświatowego oraz praktyczne ich zastosowania. Opisuje też różnego rodzaju problemy organizacyjne i dylematy z tym związane.

Słowa kluczowe: specjalne potrzeby, edukacja inkluzyjna, włączanie i wyłączanie, rozwiązania praktyczne, przepisy prawa oświatowego

\section{Including and excluding students with special needs from general educational trend - practice regulations of the existing educational law on an example of Gdańsk and more}

In this article, the author defines students with special needs and disadvantages well as inclusive education. The writer suggests options for supporting students with special needs and disadvantages in mainstreams schools, with particular focus on incorporating them into their peer groups and seperating them from these groups. The author discusses different solutions, resulting from educational law, and their application, as well as various types of organisation problems and their dilemma.

Keywords: special needs, inclusive education, including and excluding, practical approach, educational law 


\section{Wstęp - ustalenia terminologiczne}

Od wielu już lat w polskiej edukacji pojawia się określenie specjalnych potrzeb edukacyjnych, używane, między innymi, przez nauczycieli, samorządowców, decydentów i reformatorów oświaty. Po raz pierwszy specjalne potrzeby edukacyjne zostały zdefiniowane w 2010 r. przez zespół ekspertów powołanych przez ówczesnego Ministra Edukacji Narodowej w osobie Katarzyny Hall. Ustalono wtedy, że „Specjalne potrzeby edukacyjne dzieci i młodzieży wynikają ze zróżnicowanego indywidualnego sposobu nabywania wiedzy i umiejętności w procesie uczenia się, określonego zróżnicowanym ich funkcjonowaniem poznawczo-percepcyjnym" [Zespół MEN 2010: 90]. Do dziś jednak określenie to jest czysto funkcyjne, które pojawia się w rozmowach i dyskursach dotyczących oświaty oraz w naukowych opracowaniach i praktycznych instruktażach, natomiast wcale nie występuje w przepisach prawa oświatowego. $Z$ uwagi na brak jednoznacznych zapisów $\mathrm{w}$ aktach prawnych określeniu oznaczającemu uczniów o specjalnych potrzebach edukacyjnych można przypisać, zamiennie, dwa zakresy - wąski i szeroki. W wąskim ujęciu obejmuje ono uczniów z znanymi w oświacie niepełnosprawnościami ${ }^{1}$, zagrożonych niedostosowaniem społecznym i niedostosowanych społecznie, czyli tych, którzy posiadają orzeczenia o potrzebie kształcenia specjalnego, aktualnie zgodnie z rozporządzeniem MEN z dnia 9 sierpnia 2017 r. w sprawie warunków organizowania kształcenia, wychowania i opieki dla dzieci i młodzieży niepełnosprawnych, niedostosowanych społecznie i zagrożonych niedostosowaniem społecznym [Dz.U. z 2017 r., poz. 1578]. Wyróżnienie tych grup uczniów wydaje się być stosowne, gdyż w procesie swojej nauki wymagają największego wsparcia, co wiąże się z koniecznością zapewnienia im zajęć o charakterze terapeutycznym, zagwarantowania odpowiednich warunków do uczenia się, dostosowanych do ich potrzeb i możliwości metod, form i organizacji pracy, w tym nierzadko specjalistycznych pomocy dydaktycznych, a także obowiązek opracowywania dla nich odrębnej dokumentacji: wielospecjalistycznej oceny poziomu funkcjonowania oraz indywidualnego programu edukacyjno-terapeutycznego.

\footnotetext{
1 Dzieci i młodzież niepełnosprawna w systemie polskiej oświaty to osoby posiadające orzeczenia o potrzebie kształcenia specjalnego wydane przez zespoły orzekające, działające w publicznych poradniach psychologiczno-pedagogicznych. Wyżej wymienione orzeczenie może otrzymać uczeń $\mathrm{z}$ niepełnosprawnością ruchową, $\mathrm{w}$ tym $\mathrm{z}$ afazją, niepełnosprawnością intelektualną $\mathrm{w}$ stopniu lekkim, umiarkowanym i znacznym, $\mathrm{z}$ autyzmem, w tym zespołem Aspergera, niewidomy i słabowidzący, niesłyszący i słabosłyszący, z niepełnosprawnościami sprzężonymi (dwie lub więcej $\mathrm{z}$ ww. niepełnosprawności). Rodzaje niepełnosprawności są jednak wybrane i mocno ograniczone $\mathrm{w}$ stosunku do tych uznawanych $\mathrm{w}$ systemie pozaoświatowym np. medycznym, gdzie zgodnie z przyjętymi założeniami DSM V i ICD 11 orzeczenia wydawane przez Powiatowe i Miejskie Zespoły ds. Orzekania o Niepełnosprawności mogą otrzymać także osoby przewlekle i psychicznie chore, $\mathrm{z}$ chorobami uwarunkowanymi genetycznie, z zaburzeniami zachowania i emocji, z zaburzeniami komunikacji werbalnej oraz z różnymi uszkodzeniami neurologicznymi.
} 
Z kolei szerokie ujmowanie uczniów o specjalnych potrzebach edukacyjnych zakłada wszystkie te grupy dzieci i młodzieży, które w szkołach i placówkach należy obejmować pomocą psychologiczno-pedagogiczną, rozumianą jako „rozpoznawanie i zaspokajanie indywidualnych potrzeb rozwojowych i edukacyjnych oraz rozpoznawanie indywidualnych możliwości psychofizycznych ucznia i czynników środowiskowych wpływających na jego funkcjonowanie w przedszkolu, szkole i placówce, $\mathrm{w}$ celu wspierania potencjału rozwojowego ucznia i stwarzania mu warunków do jego aktywnego i pełnego uczestnictwa w życiu przedszkola, szkoły i placówki oraz w środowisku społecznym" [rozporządzenie MEN z dnia 9 sierpnia 2017 r. w sprawie zasad organizacji i udzielania pomocy psychologiczno-pedagogicznej w publicznych przedszkolach, szkołach i placówkach; Dz. U. z 2017 r., poz. 1591]. Potrzeba udzielenia uczniowi tego rodzaju pomocy nie jest uwarunkowana posiadaniem przez niego orzeczenia czy nawet opinii poradni psychologiczno-pedagogicznej, ale wynika z konieczności wspierania jego rozwoju z uwagi na: niepełnosprawności, niedostosowanie społeczne lub zagrożenie tym niedostosowaniem, zaburzenia zachowania i emocji, szczególne uzdolnienia, specyficzne trudności w uczeniu się, deficyty kompetencji i zaburzenia sprawności językowych, chorobę przewlekłą, sytuację kryzysową i traumatyczną, niepowodzenia edukacyjne, zaniedbania środowiskowe związane z sytuacją bytową ucznia i jego rodziny oraz sposób spędzania czasu wolnego i kontaktów środowiskowych, trudności adaptacyjne związane z różnicami kulturowymi lub ze zmianą środowiska edukacyjnego, w tym z wcześniejszym kształceniem za granicą. To nauczyciele, wychowawcy i inni specjaliści ze szkół i placówek, w toku codziennej pracy, powinni rozpoznawać potrzeby i możliwości swoich uczniów w celu określania ich mocnych stron, predyspozycji, zainteresowań i uzdolnień oraz przyczyn niepowodzeń edukacyjnych lub trudności w funkcjonowaniu, $\mathrm{w}$ tym barier i ograniczeń utrudniających to funkcjonowanie i uczestnictwo $\mathrm{w}$ środowisku rówieśniczym, tym samym więc, odnosząc się do wdrażanych w życie idei wyrównywania szans edukacyjnych wszystkich uczniów oraz zapewniania im odpowiednich warunków do nauki, podejście szerokie wydaje się być tym właściwym. Choć można także dyskutować, czy faktycznie specjalne potrzeby edukacyjne w ogóle istnieją. Niektórzy uważają bowiem, że potrzeby wszystkich uczniów są takie same, w tym dążenie do wszechstronnego rozwoju czy nabywanie kompetencji społecznych, tylko drogi do ich zaspokajania mogą być różne [Kosakowski 2001: 287-293]. Przy takim rozumowaniu specjalne potrzeby edukacyjne należy traktować jako swoisty skrót myślowy odnoszący się do zapewnienia konkretnym uczniom czy określonym grupom dzieci i młodzieży szczególnych warunków i profesjonalnej pomocy w specjalnym realizowaniu swoich potrzeb, nie tylko edukacyjnych. 
Szeroko ujmowana (rozumiana) grupa uczniów ze specjalnymi potrzebami edukacyjnymi, tak jak ich rówieśnicy, musi w naszym kraju realizować swoje roczne obowiązkowe przygotowanie przedszkolne, obowiązek szkolny i obowiązek nauki. W Polsce istnieją dwa generalne systemy kształcenia dzieci i młodzieży: segregacyjny i niesegregacyjny. Ten pierwszy tworzą szkoły i placówki specjalne, przeznaczone wyłącznie dla uczniów posiadających orzeczenia o potrzebie kształcenia specjalnego (a więc dla uczniów ze specjalnymi potrzebami edukacyjnymi w ujęciu wąskim) z uwagi na jednorodny rodzaj dysfunkcji lub ich sprzężenie. Są więc szkoły i placówki dla dzieci z niepełnosprawnością intelektualną, z niepełnosprawnościami ruchowymi, niewidomych i słabowidzących, niesłyszących i słabosłyszących, z autyzmem, a także ośrodki socjoterapeutyczne i wychowawcze dla uczniów zagrożonych niedostosowaniem społecznym lub już niedostosowanych. Drugi system propaguje idee tzw. wspólnego nurtu, czyli edukację wspólną dla wszystkich, w tym dla uczniów ze specjalnymi potrzebami edukacyjnymi w ujęciu szerokim. W Polsce niesegregacyjny system kształcenia obejmuje następujące formy: integracyjną (gdzie oddział integracyjny zorganizowany w szkole ogólnodostępnej zbudowany jest zgodnie z modelem: do 5 uczniów z różnym stopniem i rodzajem niepełnosprawności, od 15 do 20 wszystkich uczniów razem, dodatkowy nauczyciel z kwalifikacjami z zakresu pedagogiki specjalnej [rozporządzenie MEN z dnia 17 marca 2017 r. w sprawie szczegółowej organizacji publicznych szkół i publicznych przedszkoli - Dz.U. z 2017 r., poz. 649 z późn. zm.] i włączającą (przyjmując, że pojedynczy uczniowie z różnymi specjalnymi potrzebami edukacyjnymi, bez wyjątku, uczęszczają do klas ogólnodostępnych razem ze swoimi pełnosprawnymi rówieśnikami). Przy czym ww. włączanie rozumiane i traktowane jest bardzo różnie - jako jedna z form kształcenia integracyjnego, jako jej poszerzona odmiana, albo też jako jej ewolucyjnie wyższa forma [Szumski 2010: 12-27]. Synonimem dla edukacji włączającej jest edukacja inkluzyjna, która uznaje różnorodność w klasie szkolnej jako zjawisko naturalne, zaś jej efektem jest obecność (dostęp do edukacji), uczestnictwo (jakość doświadczeń związanych z uczeniem się) oraz podnoszenie osiągnięć (procesy uczenia się i uzyskiwane wyniki) wszystkich uczniów w ogóle [Europejska Agencja ds. Specjalnych Potrzeb i Edukacji Włączającej 2014: 13]. Najważniejszym jednak zadaniem inkluzji i jednocześnie jej głównym mottem to bycie niewykluczonym [Speck 2013: 56-110], do czego właśnie mają przyczyniać się szkoły i placówki ogólnodostępne. Nie znaczy to jednak, że szkoły specjalne są gorsze czy niepotrzebne. Lata doświadczeń w zakresie wdrażania integracyjnych idei pokazały bowiem, że samo umożliwienie uczęszczania różnym uczniom ze specjalnymi potrzebami edukacyjnymi, do jednej, ogólnodostępnej szkoły czy klasy, nie gwarantuje wcale realizacji kluczowego przesłania edukacji włączającej, czyli edukacji z korzyścia dla wszystkich [Europejska Agencja ds. Specjalnych Potrzeb i Edukacji Włączającej 
2014: 13-14]. Są bowiem uczniowie dla których szkoła specjalna była, jest i jeszcze długo będzie najlepszym miejscem kształcenia. Uniemożliwienie im pobierania nauki w miejscach dla nich najbardziej dogodnych, najlepiej dostosowanych do ich potrzeb i możliwości, dyskredytując tym samym ich inność i prawo do niej to zwyczajna ekskluzja, czyli wynaturzona zasada inkluzji [Speck 2013: 65).

Edukacja inkluzyjna (włączająca) stanowi pewną część wdrażanych w życie humanistycznych i antydyskryminacyjnych idei, poprzez stwarzanie warunków do równego, godnego i wspólnego funkcjonowania w szkolnym środowisku wszystkich uczniów, ze szczególnym uwzględnieniem tych, narażonych z różnych powodów, na społeczne wykluczenie czy marginalizację. W dążeniu do inkluzji wszystkich grup uczniów ze specjalnymi potrzebami edukacyjnymi (w ujęciu szerokim), dla budowania, rozwijania i doskonalenia wspólnego nauczania przyjmuje się założenia Konwencji o prawach osób niepełnosprawnych - choć docelowo Konwencja odnosi się głównie do uczniów ze specjalnymi potrzebami edukacyjnymi w ujęciu wąskim [www.rpo.gov.pl]. Konwencja ta została przyjęta 13 grudnia 2006 r. przez Zgromadzenie Ogólne Narodów Zjednoczonych i uważana jest za ważny i wielki krok w kierunku tworzenia społeczeństwa i środowiska otwartego dla wszystkich. 23 grudnia 2010 r. Unia Europejska ratyfikowała Konwencję, co oznacza, że zobowiązała kraje członkowskie do przestrzegania jej postanowień, wprowadzania jej zapisów do własnych systemów prawnych, planowania strategicznych rozwiązań oraz procedur i praktyk na rzecz osób niepełnosprawnych. W imieniu naszego kraju w dniu 6 września 2012 r. Prezydent Bronisław Komorowski przyjął, ratyfikował i zatwierdził ww. Konwencję - tym samym Polska, jako Państwo stała się także Strona, zobligowaną do wdrażania w życie jej zapisów. Artykuł 24 Konwencji w całości dotyczy edukacji - powszechnej, wspólnej i takiej samej dla wszystkich, propagując jako cel polityki oświatowej naszego państwa wprowadzanie i popularyzację włączającego modelu kształcenia. W listopadzie 2013 r. Europejska Agencja ds. Specjalnych Potrzeb i Edukacji Włączającej (Agencja ta wcześniej funkcjonowała pod nazwą Europejska Agencja na rzecz Rozwoju Edukacji Uczniów ze Specjalnymi Potrzebami Edukacyjnymi) zorganizowała konferencję, częścią której była otwarta debata właśnie na temat edukacji włączającej. W debacie wzięli udział decydenci poszczególnych krajów ds. oświaty, naukowcy, nauczyciele, a także osoby niepełnosprawne i ich rodziny. Nie poruszano już problematyki czym jest włączanie ani czy jest potrzebne, ale zajmowano się kwestiami co zrobić, aby można było je osiagnać. Także Polska zmierza się właśnie $\mathrm{z}$ tym problemem. 


\section{Włączanie - różne możliwości organizacji wspólnej edukacji}

Nawiązując do wcześniejszych rozważań, bardzo ważnym czynnikiem dla skutecznej edukacji i możliwości zaspokajania różnych potrzeb każdego z uczniów ze specjalnymi potrzebami edukacyjnymi wydaje się być dokonanie wyboru najlepszej, odpowiedniej dla niego formy kształcenia. Nie zawsze bowiem pełne włączenie takiego ucznia w tzw. główny nurt jest możliwe, a czasami także nie jest wcale dla niego najlepsze. I nie mam tu na myśli dokonywania wyboru pomiędzy szkołą ogólnodostępną, integracyjną czy specjalną, ale możliwość korzystania z różnych form pośrednich czy kombinowanych. Nie przedstawiam także przykładów tzw. idealnego włączania, kiedy to pojedynczy uczeń ze specjalnymi potrzebami edukacyjnymi, pomimo zdiagnozowanych dysfunkcji rozwojowych, uczęszcza do klasy ogólnodostępnej oraz przy wsparciu nauczycieli i pełnej akceptacji swoich rówieśników uzyskuje oczekiwane, czyli wysokie, efekty edukacyjne oraz utrzymuje satysfakcjonujące go kontakty społeczne - do tego oczywiście należy dążyć. Poniżej zamieszczam przykłady różnych rozwiązań, przemyślanych i już sprawdzonych, a wydaje się, że dających gwarancję edukacyjnych i integracyjnych sukcesów, zgodnie z maksymą: Dla każdego to, co dla niego jest naprawde najlepsze.

Gdyńska Szkoła Społeczna działa od 25 lat jako szkoła podstawowa (jeszcze także jako gimnazjum), jej organem prowadzącym jest Polskie Stowarzyszenie na rzecz Edukacji i Integracji "Tacy sami”, a funkcjonuje pod patronatem Polskiego Stowarzyszenia Pedagogów i Animatorów KLANZA. Oprócz uczniów pełnosprawnych w jej murach uczą się dzieci z poważnymi dysfunkcjami wzroku tj. słabowidzące i niewidome, posiadające ważne orzeczenia o potrzebie kształcenia specjalnego - dzieci z innymi niepełnosprawnościami czy problemami rozwojowymi nie są przyjmowane 2 . W Gdyńskiej Szkole realizowany jest proces włączania dzieci niewidomych i słabowidzących do klas ogólnodostępnych, które na ogół liczą nie więcej niż 18 uczniów. Gdy jest taka potrzeba do klasy dodatkowo zatrudniany jest tyflopedagog, jako nauczyciel wspierający, ale rzadko, gdyż większość nauczycieli tzw. przedmiotowców ukończyła studia podyplomowe z zakresu tyflopedagogiki, a cała kadra pedagogiczna ustawicznie szkoli się w zakresie pracy z uczniami z dysfunkcjami wzrokowymi, co skutkuje takim planowaniem zajęć lekcyjnych i stosowaniem takich pomocy dydaktycznych, by wszystkie dzieci mogły z nich korzystać, a także przekłada się na umiejętność budowania in-

2 Z możliwości kształcenia w Gdyńskiej Szkole Społecznej korzystają także uczniowie z dużymi dysfunkcjami wzrokowymi z miasta Gdańska, środki finansowe na gdańskiego ucznia są przekazywane na zasadzie porozumienia pomiędzy prezydentami tych dwóch miast, choć już sam dowóz gdańskiego ucznia do Szkoły w Gdyni jego rodzice muszą organizować w swoim własnym zakresie. 
tegracji uczniów sprawnych i niepełnosprawnych. Sprzyja temu też od kilku lat realizowany w Szkole projekt "Oczko" ukierunkowany na wspólne spędzanie czasu wolnego w czasie ferii, wakacji, dni wolnych, którego celem jest rozwijanie pasji i zainteresowań oraz dobra zabawa. Wszyscy uczniowie niepełnosprawni uczęszczają na dodatkowe zajęcia rewalidacyjne, tzw. tyflopedagogiczne, przeznaczane na usprawnianie widzenia, naukę wykorzystywania tzw. resztek wzrokowych oraz doskonalenie koordynacji wzrokowo-ruchowej, mają zajęcia z nauki pisma punktowego brailla oraz dodatkowe zajęcia informatyczne. Szkoła posiada specjalistyczny sprzęt i inne pomoce dydaktyczne do pracy z uczniami $\mathrm{z}$ dysfunkcjami wzrokowymi, podręczniki pisane w braillu, komputery braillowskie, maszyny do pisania i inne. Szkoła ściśle współpracuje ze Specjalnym Ośrodkiem Szkolno-Wychowawczym dla Dzieci i Młodzieży Słabowidzącej i Niewidomej w Bydgoszczy, korzystając ze wsparcia zatrudnionych tam tyflospecjalistów. Tak więc zarówno pod względem edukacyjnym, jak i integracyjnym Gdyńska Szkoła Społeczna to bardzo dobre miejsce dla uczniów z poważnymi dysfunkcjami wzrokowymi, tym samym do wdrażania idei włączających, choć wyłącznie dla wybranego rodzaju niepetnosprawności.

Na podobnej zasadzie funkcjonuje w Gdańsku Szkoła Podstawowa Nr 24, która prowadzi klasy integracyjne o tradycyjnej strukturze tj. przyjmując do szkolnych oddziałów do 5 uczniów z orzeczeniami o potrzebie kształcenia specjalnego. Jednak w wyniku stałej współpracy ze Specjalistycznym Ośrodkiem Diagnozy i Rehabilitacji Dzieci i Młodzieży z Wadą Słuchu PZG w Gdańsku oraz z Poradnią Psychologiczno-Pedagogiczną Nr 7, która diagnozuje i wydaje orzeczenia dzieciom i młodzieży z dysfunkcjami słuchowymi dla całego miasta Gdańska, uczniów słabosłyszących i niesłyszących jest $\mathrm{w}$ tej szkole wyjątkowo dużo. Są nawet takie klasy integracyjne, jak np. aktualna klasa III, do której uczęszcza 5 uczniów słabosłyszących, w tym dwie uczennice posługujące się językiem migowym. W klasie tej jest oczywiście zatrudniony dodatkowy nauczyciel z kwalifikacjami z zakresu pedagogiki specjalnej - surdopedagog, który także zna język migowy. W Szkole jest więcej nauczycieli, którzy zdobyli dodatkowe uprawnienia z zakresu surdopedagogiki, w tym z języka migowego - dzięki temu mogą porozumiewać się z niesłyszącymi uczniami, prowadzić z nimi w sposób profesjonalny zajęcia rewalidacyjne, a także integrować całą społeczność szkolną poprzez realizowane $\mathrm{w}$ formie zajęć pozalekcyjnych kółka zainteresowań, poświęcone nauce języka migowego uczniów pełnosprawnych (zainteresowanie wśród dzieci tą formą komunikacji jest bardzo duże). Ponadto w Szkole działa chór, złożony z uczniów słyszących i niesłyszących, który posiada repertuar prezentowany w języku migowym i bierze udział w konkursach i festiwalach zarówno szkół integracyjnych, jak i organizowanych przez szkoły specjalne, w tym np. przez Ośrodek Szkolno-Wychowawczy Nr 2 dla Niesłyszących i Słabosłyszących w Wejherowie „Moje 
ręce migają muzykę". Dodatkowym atutem dla środowiska szkolnego jest fakt, że tzw. nauczyciele migający, mają możliwość swobodnego komunikowania się z rodzicami, którzy sami są osobami niesłyszącymi. Tak więc tradycyjne wywiadówki mogą być prowadzone $\mathrm{w}$ dwóch językach, werbalnym i migowym, a rodzic niesłyszący może przyjść do pedagoga czy nauczycieli i porozmawiać o trudnościach dziecka i sposobach wspierania go w nauce szkolnej. Tym samym szkoła wychodzi naprzeciw problemom coraz głośniej podnoszonych w Polsce przez Stowarzyszenie CODA/KODA (co oznacza słyszące dzieci niesłyszących rodziców) i włącza się w walkę z marginalizacją osób niesłyszących.

Z kolei Szkoła Podstawowa Nr 69 w Gdańsku nawiązała współpracę z Instytutem Wspomagania Rozwoju Dziecka, rezultatem czego jest wspólna realizacja projektu pod nazwą „Model edukacji włączającej dla uczniów z zaburzeniami ze spektrum autyzmu w klasach I - III szkoły podstawowej". Ministerstwo Edukacji Narodowej przyznało ww. projektowi status eksperymentu pedagogicznego, który aktualnie jest realizowany pod merytoryczną opieką Instytutu Psychologii Uniwersytetu Gdańskiego [zgodnie z artykułem 45 ustawy Prawo Oświatowe z dnia 14 grudnia 2016 r., Dz.U. z 2017 r., poz. 59]. W roku szkolnym 2017/2018 powołano I klasę specjalną dla 4 uczniów z autyzmem (ale intelektualnie sprawnych), z których każdy ma swojego indywidualnego nauczyciela - specjalistę. Uczniowie z klasy specjalnej włączani są, całą grupą lub indywidualnie (oczywiście razem ze swoimi nauczycielami), w wybrane zajęcia równoległej ogólnodostępnej klasy I, na miarę ich możliwości i potrzeb. Pełnosprawni uczniowie zarówno klasy, jak i szkoły, także zostali (i nadal są) przygotowani na przyjęcie swoich rówieśników, których zachowania często wydają się dziwne i zaskakujące, poprzez warsztaty prowadzone przez psychologów. Równolegle z problematyką osób autystycznych zostali zapoznani wszyscy nauczyciele, pracownicy pomocniczy szkoły i rodzice uczniów pełnosprawnych. Eksperyment stanowi swoiste przygotowywanie uczniów z autyzmem do samodzielnego funkcjonowania w zespole klasowym na drugim etapie edukacyjnym tj. od klasy IV.

Sam pomysł organizacji tzw. okresu przygotowawczego do włączenia w grupę pełnosprawnych rówieśników dzieci niepełnosprawnych wcale nie jest nowy - w 1990 roku w Gdańsku w Szkole Podstawowej Nr 5 powstała „zerówka” specjalna, do której uczęszczało pięcioro dzieci z porażeniem mózgowym, w kolejnym roku szkolnym te same dzieci jeszcze raz realizowały program klasy " 0 " ale już w konwencji integracyjnej razem z dziećmi pełnosprawnymi, z którymi potem uczyły się przez następne osiem lat33.

\footnotetext{
Organizacja klas specjalnych na terenie szkół ogólnodostępnych jest oczywiście możliwa, ale sama w sobie nie stanowi o włączaniu. Możemy o nim mówić dopiero wtedy, gdy będą świadomie i planowo podejmowane różnorodne działania na rzecz integracji uczniów klas specjalnych i klas ogólnodostępnych, a więc ich wspólny udział w imprezach i uroczystościach szkolnych, wycieczkach,
} 
Jedną z cech charakterystycznych dla klasy/oddziału integracyjnego jest obecność dodatkowego nauczyciela z przygotowaniem z zakresu pedagogiki specjalnej. By uczniom posiadającym orzeczenie o potrzebie kształcenia specjalnego pomóc w pełnym włączaniu do klasy/oddziału ogólnodostępnego (a nie tylko integracyjnego), dziś już nieaktualnym rozporządzeniem MEN z dnia 7 sierpnia 2015 r. w sprawie warunków organizowania kształcenia, wychowania i opieki dla dzieci i młodzieży niepełnosprawnych, niedostosowanych społecznie i zagrożonych niedostosowaniem społecznym [Dz.U. z 2015 r., poz. 1113], wprowadzono tam tzw. dodatkowe osoby dorosłe. Od 1 stycznia 2016 r. w szkołach i placówkach ogólnodostępnych zatrudnia się ( $\mathrm{w}$ przypadku uczniów z autyzmem lub z niepełnosprawnościami sprzężonymi) lub można zatrudnić (w przypadku uczniów z innym rodzajem niepełnosprawności, niedostosowaniem społecznym lub zagrożeniem tym niedostosowaniem) nauczycieli posiadających kwalifikacje z zakresu pedagogiki specjalnej (w celu współorganizowania kształcenia), asystentów nauczycieli (aktualni decydenci oświaty wycofali się z tej formy wsparcia $\mathrm{z}$ uwagi na niejasność roli osoby pełniącej funkcję takiego asystenta na terenie klasy czy szkoły) lub pomoce nauczycieli (osoby pełniące te funkcje nie muszą mieć przygotowania pedagogicznego, zatrudniane są na podstawie kodeksu pracy i zaliczane do grupy pracowników obsługi, realizujących z uczniem zadania organizacyjne i techniczne) [Zespół ORE 2015: 116-117]. Takie możliwości wspierania uczniów z orzeczeniami o potrzebie kształcenia specjalnego podtrzymało także aktualne rozporządzenie MEN z dnia 9 sierpnia 2017 r. w sprawie warunków organizowania kształcenia, wychowania i opieki dla dzieci i młodzieży niepełnosprawnych, niedostosowanych społecznie $\mathrm{i}$ zagrożonych niedostosowaniem społecznym [Dz.U. z 2017 r., poz. 1578]. I tak, np. dla Kuby, ucznia klasy VI szkoły podstawowej, u którego zdiagnozowano całościowe zaburzenia rozwoju (posiadającego orzeczenie o potrzebie kształcenia specjalnego z uwagi na autyzm), uczęszczającego do klasy ogólnodostępnej, zatrudniono dodatkowego nauczyciela - pedagoga specjalnego. By Kuba mógł aktywnie brać udział w zajęciach lekcyjnych, musi mieć zapewnione wsparcie nauczyciela, którego zadaniami są, między innymi: nakierowywanie uwagi chłopca na pracę edukacyjną $w$ toku zajęć lekcyjnych, przygotowywanie dla niego specjalnych kart pracy dostosowanych do potrzeb i możliwości na konkretne zajęcia, stosowanie żetonowego systemu planowania i nagradzania go za wykonanie poszczególnych części zadań,

zajęciach pozalekcyjnych, spędzaniu przerw i innych inicjatywach. W Gdańsku (i w Polsce) aktualnie takich klas jest niewiele. Stosunkowo też mało jest popularna, a bardzo sprzyjająca włączaniu, tzw. integracja kooperacyjna, w ramach której uczniowie z oddziału specjalnego mogą uczestniczyć w niektórych zajęciach lekcyjnych razem z uczniami pełnosprawnymi wybranej, „kooperującej z nimi" klasy ogólnodostępnej [szerzej: Kowalik 2011: 271-302; Gołubiew-Konieczna 2015: 111-127]. 
tłumaczenie poleceń kierowanych do całej klasy i sprawdzając, czy je rozumie, a także czuwanie i przeciwdziałanie w sytuacjach występowania zachowań agresywnych i autoagresywnych. W przypadku Jacka, ucznia już klasy V szkoły podstawowej, skorzystano ze wsparcia pomocy nauczyciela. Jacek jest uczniem z czterokończynowym dziecięcym porażeniem mózgowym i porusza się na wózku inwalidzkim - posiada orzeczenie o potrzebie kształcenia specjalnego z uwagi na niepełnosprawność ruchową. Poza tym Jacek jest uczniem intelektualnie sprawnym i wysoko zmotywowanym do nauki. W szkole zatrudniono dodatkową osobę dorosłą, która obecna jest z uczniem na zajęciach lekcyjnych i podczas przerw. Pomaga mu w przygotowywaniu podręczników na zajęcia lekcyjne, sporządzaniu notatek z lekcji, porządkowaniu miejsca pracy, spożywaniu śniadania i obiadu w szkolnej stołówce, w korzystaniu z toalety, a także towarzyszy mu podczas wyjść poza teren szkoły oraz na klasowych wycieczkach.

Omawiając różne propozycje rozwiązań inkluzyjnych (włączających) nie sposób pominąć uczniów przewlekle chorych, posiadających orzeczenia o potrzebie indywidualnego nauczania. Są wśród nich tacy, którym stan zdrowia zupełnie uniemożliwia uczęszczanie do szkoły, więc ich nauka i kontakt ze zdrowym rówieśnikiem musi odbywać się na terenie domu, albo w formie osobistej np. poprzez odwiedziny, albo wirtualnej np. poprzez listy, telefony, maile. Zgodnie z nowym rozporządzenie MEN z dnia 9 sierpnia $2017 \mathrm{r}$. w sprawie indywidualnego rocznego obowiązkowego przygotowania przedszkolnego dzieci oraz indywidualnego nauczania dzieci i młodzieży [Dz. U. z 2017 r., poz. 1616] uczniowie, którym stan zdrowia znacznie utrudnia uczęszczanie do szkoły zajęcia w zakresie indywidualnego nauczania również realizują na terenie domu - tygodniowy wymiar godzin realizowany $\mathrm{w}$ systemie jeden na jeden $\mathrm{z}$ nauczycielami określa ww. rozporządzenie. Mogą natomiast przychodzić/przyjeżdżać do szkoły na różnego rodzaju uroczystości i imprezy szkolne, zajęcia rozwijające ich zainteresowania i uzdolnienia, zajęcia specjalistyczne, zajęcia z zakresu doradztwa zawodowego oraz wybrane zajęcia edukacyjne. $Z$ tej formy nauczania, a jednocześnie włączania w system szkolno-klasowy, korzysta Filip, który jest uczniem klasy V szkoły podstawowej, posiadającym dwa orzeczenia: o potrzebie kształcenia specjalnego z uwagi na niepełnosprawność ruchową (Filip cierpi na rdzeniowy zanik mięśni, porusza się na wózku inwalidzkim, ma też mało sprawne ręce) i o potrzebie indywidualnego nauczania (Filip ma bardzo niską wydolność swojego organizmu i szybko się męczy, a także często zapada na infekcje, szczególnie w okresie jesienno-zimowym, co jest bardzo niebezpieczne dla jego życia). Filip uczy się w domu, do szkoły jednak przyjeżdża prawie codziennie na dwie godziny (jeżeli stan zdrowia mu na to pozwala, co często się zmienia) i w tym czasie ma zapewniane zajęcia rewalidacyjne pod postacią rehabilitacji ruchowej i terapii logopedycznej oraz zajęcia ze swoją klasą takie jak: godzina wychowawcza, plastyka, muzyka, historia, 
język obcy. Chłopiec jeździ też ze swoimi rówieśnikami na wycieczki i inne wyjścia poza teren placówki, ale wtedy towarzyszy mu dodatkowa osoba dorosła: rodzic lub wolontariusz. Ta forma edukacji Filipa sprawdziła się w roku ubiegłym, więc także w bieżącym roku szkolnym będzie kontynuowana.

\section{Wyłączanie - nowa forma wspierania edukacji uczniów ze specjalnymi potrzebami edukacyjnymi}

Z inkluzją - integracją i włączaniem związana jest konieczność zapewnienia uczniom, którzy tego potrzebują, odpowiednich udogodnień i ułatwień w procesie nauki, niezbędnych warunków do zdobywania wiedzy oraz usprawniania i doskonalenia mniej sprawnych funkcji, a także rozwijania uzdolnień i predyspozycji. Wśród nich wyróżnić należy, oczywiście w odniesieniu do stwierdzonego rodzaju specjalnych potrzeb, łącznie lub opcjonalnie: dostosowania w zakresie realizacji odpowiednich podstaw programowych, ocenianie postępów edukacyjnych zgodnie $\mathrm{z}$ indywidualnymi możliwościami, zwolnienie z nauki drugiego języka obcego, zdawanie egzaminów zewnętrznych w warunkach i/lub formach dostosowanych do stwierdzonych dysfunkcji rozwojowych, zapewnienie dodatkowych zajęć rewalidacyjnych, socjoterapeutycznych, resocjalizacyjnych i innych specjalistycznych oraz zajęć z zakresu pomocy psychologiczno-pedagogicznej, naukę z wykorzystaniem specjalnie opracowanych/dostosowanych podręczników i innych pomocy dydaktycznych, przedłużanie etapów edukacyjnych oraz korzystanie z możliwości wyłączania z wybranych zajęć lekcyjnych. Ostatnia propozycja wspierania edukacji uczniów ze specjalnymi potrzebami edukacyjnymi jest pomysłem nowym, możliwym do stosowania dopiero od września $2017 \mathrm{r}$.

W odniesieniu do uczniów niepełnosprawnych, niedostosowanych i zagrożonych niedostosowaniem społecznym (a więc ze specjalnymi potrzebami w ujęciu wąskim) możliwość ich wyłączania pojawiła się $\mathrm{w}$ dwóch nowych rozporządzenia MEN, a mianowicie $\mathrm{w}$ rozporządzeniu $\mathrm{z}$ dnia 9 sierpnia $2017 \mathrm{r}$. $\mathrm{w}$ sprawie warunków organizowania kształcenia, wychowania i opieki dla dzieci i młodzieży niepełnosprawnych, niedostosowanych społecznie i zagrożonych niedostosowaniem społecznym [Dz. U. z 2017 r., poz. 1578] oraz w rozporządzeniu z dnia 7 września 2017 roku w sprawie orzeczeń i opinii wydawanych przez zespoły orzekające działające $\mathrm{w}$ publicznych poradniach psychologiczno-pedagogicznych [Dz. U. z 2017 r., poz. 1743]. Wyżej wymienione rozporządzenia podniosły, że uczniowie (dotyczy także dzieci realizujących w szkołach podstawowych lub $\mathrm{w}$ przedszkolach swoje roczne obowiązkowe przygotowanie przedszkolne) mogą być wyłączani w trakcie zajęć grupowych po to, by realizować wybrane za- 
jęcia tzw. dydaktyczne, indywidualnie lub w grupie liczącej do 5 uczniów, jeżeli oczywiście napotykają trudności w funkcjonowaniu wspólnie z oddziałem „zerówkowym" lub klasowym. Wydaje się, że pomysł związany z możliwością wyłączania tej grupy uczniów był pokłosiem dużego protestu rodziców dzieci posiadających tzw. podwójne orzeczenia: o potrzebie kształcenia specjalnego i o potrzebie indywidualnego nauczania, na nakaz realizacji zajęć z zakresu indywidualnego nauczania wyłącznie na terenie domu - w myśl rozporządzenia MEN $\mathrm{z}$ dnia 9 sierpnia 2017 roku w sprawie indywidualnego obowiązkowego rocznego przygotowania przedszkolnego dzieci i indywidualnego nauczania dzieci i młodzieży [Dz. U. z 2017 r., poz. 1616].

W latach ubiegłych bowiem orzeczenie o potrzebie indywidualnego nauczania umożliwiało korzystanie z tzw. włączania - indywidualne nauczanie realizowane było na terenie szkoły w odrębnym pomieszczeniu w ilości godzin wskazywanych przez przepisy prawa oświatowego, zaś dodatkowy czas pobytu w szkole, praktycznie nieograniczony, uczniowie ci spędzali na zajęciach lekcyjnych w swoich oddziałach klasowych. Zjawisko to było nagminne, a często nawet doprowadzało do tego, że uczniowie posiadający prawo do nauczania indywidualnego, często z racji choroby, spędzali na terenie szkół zdecydowanie więcej czasu, niż ich pełnosprawni i zdrowi rówieśnicy, uczęszczając na zajęcia klasowo-lekcyjne do południa, a w godzinach popołudniowych realizując indywidualne nauczanie w charakterze korepetycji. Nowe przepisy w sposób istotny zmniejszyły ten proceder, ale umożliwiły uczniom niepełnosprawnym i zagrożonym niedostosowaniem społecznym korzystanie z prawa do ww. wyłączania.

W sytuacji wyłączania z zapewnieniem nauki w formie zajęć indywidualnych niektórych przedmiotów jest Kasia, uczennica klasy VII szkoły podstawowej, posiadająca orzeczenie o potrzebie kształcenia specjalnego z uwagi na niepełnosprawność sprzężoną - Kasia jest dziewczynką niewidomą, słabosłyszącą i niepełnosprawną intelektualne $\mathrm{w}$ stopniu lekkim, której rodzice wybrali pobliską szkołę integracyjną jako miejsce edukacji ich córki. Kasia nie jest w stanie pracować z pozostałymi rówieśnikami z klasy nawet mając zapewnione wsparcie przypisanego do klasy dodatkowego nauczyciela - pedagoga specjalnego, szczególnie w zakresie przedmiotów ścisłych i języka polskiego (Kasia posługuje się pismem punktowym Brailla). Nauka Kasi na terenie szkoły wygląda więc w ten sposób, że ilość zajęć z poszczególnych przedmiotów jest dla uczennicy tożsama z ilością zajęć pełnosprawnych uczniów klasy VII, natomiast Kasia na niektóre zajęcia uczęszcza razem ze swoją klasą, a inne ma prowadzone $\mathrm{w}$ formie indywidualnej w ilości 10 godzin lekcyjnych w tygodniu przeznaczonych na naukę matematyki, fizyki, chemii i języka polskiego. Wydaje się, że tym samym wybrano dla Kasi formę edukacji, dającą gwarancję największej skuteczności w systemie ogólnodostępnym/integracyjnym. 
W dużo mniej sformalizowanej sytuacji znajduje się Michał, uczeń posiadający orzeczenie o potrzebie kształcenia specjalnego z uwagi na niepełnosprawność sprzężoną, w tym niepełnosprawność intelektualną w stopniu umiarkowanym i dużą wadę wzroku. Michał uczęszcza do szkoły i klasy ogólnodostępnej (III klasy gimnazjalnej), a z tytułu sprzężonej niepełnosprawności zatrudniono dodatkowego nauczyciela posiadającego kwalifikacje z zakresu pedagogiki specjalnej oligofrenopedagoga, jako osoby współorganizującej jego kształcenie. Michał pracuje zgodnie z indywidualnie opracowanym dla niego programem skonstruowanym na bazie podstawy programowej dla uczniów z niepełnosprawnością intelektualną w stopniu umiarkowanym i znacznym [rozporządzenie MEN z dnia 14 lutego $2017 \mathrm{r}$. w sprawie podstawy programowej wychowania przedszkolnego oraz podstawy programowej kształcenia ogólnego dla szkoły podstawowej, w tym dla uczniów z niepełnosprawnością intelektualną w stopniu umiarkowanym lub znacznym, kształcenia ogólnego dla branżowej szkoły I stopnia, kształcenia ogólnego dla szkoły specjalnej przysposabiającej do pracy oraz kształcenia ogólnego dla szkoły policealnej Dz. U. z 2017 r., poz. 356]. Obecność Michała na wszystkich godzinach lekcyjnych ze swoją klasą jest niezasadna, gdyż chłopiec nie rozumie wielu omawianych $\mathrm{w}$ trakcie zajęć zagadnien. Wyłączanie chłopca $\mathrm{z}$ wybranych zajęć lub tylko ich fragmentów leży całkowicie w gestii pedagoga specjalnego, który mając do dyspozycji dodatkowe pomieszczenie znajdujące się obok sali lekcyjnej, wychodzi tam z Michałem, gdy uznaje to za sensowne i już w formie indywidualnej realizuje z uczniem jego treści programowe.

Z kolei przykładem wyłączania uczniów i organizowania im nauki w grupie do pięciu osób jest realizowana w Szkole Podstawowej Nr 57 w Gdańsku już od trzech lat, innowacja pedagogiczna w postaci „Klasy z częściową integracją jako optymalnej formy włączania dzieci z zespołem Downa do szkół ogólnodostępnych". Swoją innowacyjność ta integracyjna klasa (aktualnie już III) zawdzięcza jednolitej grupie uczniów niepełnosprawnych - uczęszczają do niej wyłącznie dzieci z zespołem Downa i jest ich aktualnie pięcioro (a ich rodzice związani są z działającą w Gdańsku Fundacją Rodzin i Przyjaciół Dzieci z Zespołem Downa Ja też). Dzieci z zespołem Downa posiadają orzeczenia o potrzebie kształcenia specjalnego z uwagi na niepełnosprawność intelektualną w stopniu lekkim (czworo uczniów) i w stopniu umiarkowanym (jeden uczeń). Pozostałych trzynaścioro uczniów tej klasy to dzieci pełnosprawne. Zgodnie z modelem oddziału integracyjnego dodatkowo zatrudniony jest nauczyciel z kwalifikacjami z zakresu pedagogiki specjalnej - oligofrenopedagog. Cechą wyróżniającą organizację pracy tej klasy od innych oddziałów integracyjnych jest oficjalne pozwolenie na nieuczestniczenie uczniów niepełnosprawnych we wszystkich zajęciach lekcyjnych. Integracja częściowa polega bowiem na tym, że już na poziomie wczesnej edukacji nie wszystkie lekcje odbywają się wspólnie dla całej klasy (np. na zajęcia z języka 
angielskiego uczniowie z zespołem Downa uczęszczają oddzielnie, także na niektóre zajęcia z edukacji matematycznej i polonistycznej), zaś w klasach starszych takich oddzielnych lekcji przedmiotowych będzie zdecydowanie więcej. To $\mathrm{z}$ pedagogiem specjalnym $\mathrm{w}$ odrębnym pomieszczeniu uczniowie niepełnosprawni doskonalą swoje umiejętności szkolne realizując treści przewidziane programem nauczania w swoim, wolniejszym tempie. Ponadto, zarówno uczniowie z zespołem Downa, jak i uczniowie pełnosprawni, pracują w oparciu o tzw. metodę krakow- ską i zgodnie z nią poznają litery, sylaby, uczą się czytania, pisania oraz poznają różne formy gramatyczne4. Tym samym udało się uniknąć swoistego zamętu, który często towarzyszy w pracy dzieciom z problemami w uczeniu się, gdy podczas zajęć lekcyjnych uczą się jedną metodą, a na zajęciach dodatkowych usprawniających, wykorzystują metodę zupełnie inną. W przypadku uczniów z zespołem Downa metoda krakowska wykorzystywana jest i przy realizacji podstawy programowej w zespole klasowym, i podczas dodatkowych zajęć rewalidacyjnych oraz logopedycznych, co niewątpliwie może mieć pozytywne przełożenie na ich efekty edukacyjne.

Z możliwości wyłączania, jako formy wspierającej, mogą korzystać nie tylko uczniowie posiadający orzeczenia o potrzebie kształcenia specjalnego - uczniowie bez ww. orzeczeń, na mocy rozporządzenia z dnia 9 sierpnia 2017 r. w sprawie zasad organizacji i udzielania pomocy psychologiczno-pedagogicznej w publicznych przedszkolach, szkołach i placówkach [Dz. U. z 2017 r., poz. 1591] mogą skorzystać z obejmowania ich tzw. zindywidualizowaną ścieżką kształcenia. Jest to możliwe tylko i wyłącznie na podstawie opinii publicznej poradni psychologiczno-pedagogicznej wskazującej na zasadność zapewnienia konkretnemu uczniowi takiej formy pomocy. Formę tę organizuje się dla uczniów wszystkich typów szkół oraz dzieci realizujących roczne obowiązkowe przygotowanie przedszkolne, które ze względu na pewne trudności w swoim funkcjonowaniu, wynikające w szczególności ze stanu zdrowia (choć oczywiście nie tylko), nie mogą realizować wszystkich zajęć dydaktycznych wspólnie z klasą - wymagają dostosowania organizacji i procesu nauczania do ich specjalnych potrzeb edukacyjnych. Zindywidualizowana ścieżka obejmuje więc wszystkie zajęcia edukacyjne, które uczeń realizuje zarówno wspólnie z oddziałem szkolnym, jak i indywidualnie. Po uwzględnieniu opinii z poradni psychologiczno-pedagogicznej, która wskazuje, między innymi zakres, w jakim uczeń nie może brać udziału w zajęciach edukacyjnych ze swoją klasą (poradnia może określić, np. jakich przedmiotów czy treści i w jakim czasie w ciągu dnia dziecko/uczeń powinno uczyć się

4 Choć metoda krakowska, czyli metoda symultanicznej nauki czytania, została opracowana docelowo jako metoda terapeutyczna dla uczniów słabosłyszących i dyslektycznych, to jednak sprawdza się $\mathrm{w}$ pracy także z uczniami sprawnymi, którym nauka czytania przychodzi bez większych problemów. 
indywidualnie), dyrektor ustala tygodniowy wymiar godzin zajęć realizowanych indywidualnie z uczniem, biorąc pod uwagę konieczność realizacji obowiązującej podstawy programowej. Pomoc uczniowi w formie zindywidualizowanej ścieżki przyznaje się wyłącznie na jeden rok szkolny i w tym czasie szkoła musi podjąć działania w celu usunięcia barier i ograniczeń utrudniających jego funkcjonowanie i uczestniczenie w życiu klasy (by mógł jak najszybciej i bez dodatkowych komplikacji powrócić $\mathrm{w}$ system tożsamy i wspólny dla jego rówieśników). Poradnia Psychologiczno-Pedagogiczna Nr 7 w Gdańsku wydała w roku ubiegłym opinie o konieczności objęcia formą zindywidualizowanej ścieżki (między innymi) trzem uczniom: Maciejowi, Łukaszowi i Adamowi.

Maciej uczęszcza do klasy II gimnazjalnej. Jest uczniem przewlekle chorym, aktualnie po dwóch przeszczepach nerek (pierwszy zabieg nie udał się i chłopiec musiał poddać się kolejnej operacji). Długo chorował, przebywał w szpitalach, w związku z czym bardzo często w szkole był nieobecny i jego zaległości programowe są olbrzymie. Bardzo był jednak zmotywowany do pracy i chciał wrócić do szkoły (przez kilka lat obejmowany był indywidualnym nauczaniem na terenie domu, ale swoją izolację od rówieśników źle wspomina). $Z$ tego też względu, by mógł uczęszczać na zajęcia ze swoją klasą, a jednocześnie nadrabiać zaległości programowe - szczególnie z matematyki i z języków obcych, został objęty zajęciami indywidualnymi na terenie szkoły właśnie z tych przedmiotów w ilości 8 godzin w tygodniu. Tak więc cztery godziny matematyki, i po dwie języka angielskiego i języka niemieckiego uczeń realizował indywidualnie w czasie, gdy jego rówieśnicy te zajęcia mieli zorganizowane $\mathrm{w}$ grupie klasowej.

Łukasz z kolei to uczeń ostatniej klasy technikum. Cierpi na depresję i zaburzenia adaptacyjne. Lekarz psychiatra, pod opieką którego uczeń znajduje się, zaproponował indywidualne nauczanie na terenie domu. Psycholog opiekujący się Łukaszem miał jednak inne zdanie - uważał, że uczeń jest także uzależniony od komputera i pozwolenie mu na przebywanie przez cały dzień w domu bez kontroli innych osób dorosłych może przyczynić się do pogłębienia tego problemu. Na podstawie opinii z Poradni objęto więc Łukasza zindywidualizowaną ścieżką z przedmiotów zawodowych na terenie szkoły w ilości 10 godzin w tygodniu, by tym samym pomóc mu zdobyć tytuł technika, a jednocześnie wymusić na nim wychodzenie z domu i „odrywanie się" od komputera.

Adam od zawsze miał trudności w funkcjonowaniu społecznym z uwagi na zaburzenia adaptacyjne i mutyzm wybiórczy. Bardzo długo i z dużymi kłopotami adaptuje się do nowych miejsc, nowych sytuacji i nowych ludzi. Z tego też powodu, w klasie VII, gdy rozpoczął obowiązkową naukę drugiego języka obcego $\mathrm{z}$ nieznanym mu nauczycielem, nie był w stanie nie tylko brać udziału w zajęciach lekcyjnych, ale czasami nawet wejść do szkolnej sali. Został więc objęty zindywidualizowaną ścieżką w ilości dwóch godzin w tygodniu, by w kameralnej i bez- 
piecznej dla niego atmosferze, rozpocząć naukę języka niemieckiego. W roku szkolnym 2018/2019, mamy nadzieję, Adam będzie już mógł uczyć się tego języka ze swoją klasą, z nauczycielem poznanym podczas zajęć indywidualnych.

Swoistym wyłączaniem jest także organizowanie klas terapeutycznych na terenach szkół ogólnodostępnych. Klasy terapeutyczne to wcale nienowe formy edukacyjne, przeznaczone dla uczniów, którzy z uwagi na trudności funkcjonowania w szkole lub w oddziale ogólnodostępnym, wynikające z pewnych zaburzeń rozwojowych lub ze stanu zdrowia, wymagają dostosowania organizacji i procesu nauczania oraz długotrwałej pomocy specjalistycznej. Każdy kandydat do nauki $w$ takiej klasie musi posiadać opinię z poradni psychologiczno-pedagogicznej, z której wynika potrzeba objęcia go tą formą pomocy - zgodnie z rozporządzeniem MEN z dnia 9 sierpnia $2017 \mathrm{r}$. w sprawie zasad organizacji i udzielania pomocy psychologiczno-pedagogicznej $\mathrm{w}$ publicznych przedszkolach, szkołach i placówkach [Dz. U. z 2017 r., poz. 1591]. Liczba uczniów w klasie terapeutycznej nie może przekraczać 15, zaś nauczanie prowadzone jest zgodnie $\mathrm{z}$ realizowanymi $\mathrm{w}$ szkole programami, $\mathrm{z}$ uwzględnieniem indywidualnych potrzeb i możliwości rozwojowych oraz psychofizycznych uczniów. Nauka w takiej klasie trwa do czasu złagodzenia lub wyeliminowania trudności ucznia i umożliwia mu powrót do „macierzystej” szkoły i klasy.

W roku szkolnym 2018/2019 Szkoła Podstawowa Nr 49 w Gdańsku otwiera pierwszy oddział terapeutyczny „Klasy na miarę” na poziomie klasy czwartej, dla uczniów ze stwierdzoną dysleksją rozwojową, a w szczególności z jej głęboką formą. Do tej klasy przyjmowani są uczniowie z terenu miasta Gdańska, u których stwierdzono specyficzne trudności w uczeniu się utrudniające edukację w tak dużym stopniu, że, pomimo prawidłowego rozwoju umysłowego i korzystania z dodatkowych zajęć korekcyjno-kompensacyjnych, gdyż nie opanowali w sposób zadawalający sztuki czytania i pisania. Oprócz nauki w mniejszej grupie klasowej uczniowie ci będą objęci stałą pomocą pedagogiczną i psychologiczną na terenie Szkoły oraz będą mieć zapewnione dodatkowe zajęcia specjalistyczne, w tym: terapię pedagogiczną, socjoterapię, zajęcia logopedyczne, biblioterapię, muzykoterapię, arteterapię oraz zajęcia rozwijające umiejętności efektywnego uczenia się. Patronat nad klasą przyjęło Polskie Towarzystwo Dysleksji.

\section{Zakończenie - problemy, wątpliwości, dylematy}

Niewątpliwie należy zgodzić się, że uczniowie ze specjalnymi potrzebami edukacyjnymi (w ujęciu szerokim) wymagają mniejszej lub większej pomocy we włączaniu się w tzw. główny nurt edukacji, lub w zapobieganiu, by z tego nurtu 
nie być wykluczanymi. Pomoc ta ma charakter bardzo często organizacyjny, chociażby właśnie przez wyłączanie ich ze wspólnych lekcji na rzecz zajęć indywidualnych. Ale należy jednocześnie pamiętać, że „do powstania szkoły inkluzyjnej nie dochodzi się poprzez dokonywanie czysto organizacyjnych zmian... Inkluzyjny profil szkoły o wiele bardziej kształtuje się w wyniku kierowania uwagi - w ramach funkcjonowania szkoły jako całości, to jest $w$ ramach pedagogicznego pojmowania procesów wychowania i kształcenia, a także w ramach praktycznego szkolnego życia, włączając w to wszystkich nauczycieli i uczniów" [Speck 2015: 273]. Omawiane zmiany organizacyjne niosą ze sobą więc określone problemy, wątpliwości i dylematy, a niektóre z nich pozwolę sobie opisać poniżej.

Jednym z problemów, często zgłaszanym zarówno przez organy prowadzące, jaki dyrektorów szkół i placówek, są pieniądze, czyli konieczności zabezpieczenia odpowiednich funduszy na kształcenie uczniów ze specjalnymi potrzebami edukacyjnymi w systemie inkluzyjnym, w tym na ich wyłączanie. Wszystko co dodatkowe, odmienne, a przede wszystkim dostosowywane do potrzeb pojedynczego ucznia, musi kosztować. Zdobycie dodatkowych funduszy na włączanie, z zastosowaniem formy wyłączającej, jest zdecydowanie prostsze $w$ odniesieniu do uczniów posiadających orzeczenia o potrzebie kształcenia specjalnego - tak jak na inne dostosowania i przywileje w procesie nauki korzystają oni z kwoty subwencji oświatowej przypadającej na każdego ucznia (zwaną wagą przeliczeniową), która, w zależności od rodzaju dysfunkcji, jest zwiększana o kwotę dodatkową, stanowiącą wielokrotność stawki bazowej, zgodnie z corocznie wydawanymi rozporządzeniami - aktualne jest rozporządzenie MEN z dnie 15 grudnia 2018 r. w sprawie sposobu podziału części oświatowej subwencji ogólnej dla jednostek samorządu terytorialnego w 2018 roku [Dz. U. z 2017 r., poz. 2395]. Tak więc, posiadając odpowiednio większe środki, można dla tych uczniów zorganizować zajęcia indywidualne lub w grupie do pięciu osób ${ }^{5}$. W przypadku pozostałych uczniów ze specjalnymi potrzebami edukacyjnymi niesione w szkołach wsparcie, $\mathrm{w}$ tym obejmowanie ich zindywidualizowaną ścieżką kształcenia, nie jest związane z żadną wagą i realizowane jest bez dodatkowych środków finansowych [Kubicki 2017]. A są one

\footnotetext{
System ww. dofinansowania jest aktualnie dyskutowany, a planowane zmiany wynikają z obaw, czy na pewno każde dziecko z ww. orzeczeniem, niezależnie od tego, do jakiej szkoły czy przedszkola uczęszcza, jest należycie wspierane dzięki zapewnieniu mu dodatkowych funduszy - choć nigdzie nie jest powiedziane, że subwencja pozyskana przez samorząd z budżetu państwa ma pokrywać w całości wydatki przeznaczana na oświatę - stanowi ona tylko jedno ze źródeł finansowania tych zadań i powinna być uzupełniania z tzw. dochodów własnych jednostek samorządu terytorialnego. W sytuacji szkół i placówek publicznych przekazywane subwencje oświatowe rozliczane są na poziomie organu prowadzącego, tzw. zbiorczo. Nie ma tu gwarancji, że każda szkoła otrzyma dokładnie tyle, ile wynoszą, naliczone na każdego ucznia do niej uczęszczającego, środki. Placówki niepubliczne, w sytuacji uczęszczania do nich ucznia z orzeczeniem o potrzebie kształcenia specjalnego, otrzymują na niego całą pulę środków finansowych, zgodne z odpowiednim algorytmem, co nosi nazwę dotacji, jednak brak elastyczności w jej wydatkowaniu jest i tu dużą wadą.
} 
potrzebne chociażby na wynagradzanie nauczycieli za prowadzenie zajęć indywidualnych. Tu jednak pieniądze mają pochodzić z puli przeznaczonej na pomoc psychologiczno-pedagogiczną, która w większości szkół i placówek nigdy nie była wystarczająca, a w przypadku konieczności zapewniania zajęć indywidualnych $\mathrm{w}$ ramach zindywidualizowanej ścieżki $\mathrm{w}$ zasadzie już na początku roku szkolnego przestaje istnieć. I stąd tak duże o obawy o możliwość realizacji tej formy pomocy w ogóle.

Kolejną trudnością, także pośrednio związaną z finansami, jest ilość godzin, które w ramach wyłączania uczniów niepełnosprawnych, zagrożonych niedostosowaniem lub niedostosowanych społecznie czy też $\mathrm{w}$ ramach zindywidualizowanej ścieżki kształcenia pozostałych uczniów ze specjalnymi potrzebami edukacyjnymi, należy przeznaczać na zajęcia indywidualne. Przepisy prawa oświatowego są tutaj elastyczne i pozostawiają dużą samodzielność szkole. W przypadku uczniów posiadających orzeczenie o potrzebie kształcenia specjalnego ilość i rodzaj zajęć indywidualnych (lub prowadzonych $\mathrm{w}$ grupie do pięciu osób) pozostawiono do decyzji szkolnego zespołu ds. specjalnych potrzeb. Nie ma nawet takiego wymogu, by zespół orzekający publicznej poradni psychologiczno-pedagogicznej wydający ww. orzeczenie zalecał tę formę wsparcia, choć oczywiście, gdy widzi taką potrzebę, powinien to zrobić. Ale to szkolny zespół podejmuje autonomiczną decyzję ostateczną, także w ciągu trwania roku szkolnego, odnotowując zarówno przyczyny niepowodzeń edukacyjnych i trudności $w$ funkcjonowaniu ucznia w oddziale klasowym, jak i zakres wskazanych w związku z tym zajęć indywidualnych, $\mathrm{w}$ wielospecjalistycznej ocenie funkcjonowania ucznia oraz $\mathrm{w}$ jego indywidualnym programie edukacyjno-terapeutycznym [rozporządzenie MEN z dnia 9 sierpnia 2017 r. w sprawie warunków organizowania kształcenia, wychowania i opieki dla dzieci i młodzieży niepełnosprawnych, niedostosowanych społecznie i zagrożonych niedostosowaniem społecznym; Dz. U. z 2017 r., poz. 1578].

W przypadku zindywidualizowanej ścieżki ustawodawca więcej uprawnień nakłada na publiczne poradnie psychologiczno-pedagogiczne, gdyż, jak wcześniej wskazywałam, ta forma wsparcia wymaga pozyskania jej opinii. Przed jej wydaniem, we współpracy z rodzicami dziecka i samą szkołą, specjalista z poradni zobligowany jest do przeprowadzenia analizy funkcjonowania ucznia z uwzględnieniem efektów dotychczas udzielonej mu pomocy psychologiczno-pedagogicznej [rozporządzenie z dnia 9 sierpnia 2017 roku w sprawie zasad organizacji i udzielania pomocy psychologiczno-pedagogicznej $\mathrm{w}$ publicznych przedszkolach, szkołach i placówkach; Dz. U. z 2017 r., poz. 1591]. I choć to poradnia na druku opinii określa zakres, $\mathrm{w}$ jakim uczeń nie może brać udziału w zajęciach grupy czy klasy, to musi brać pod uwagę wspólnie ustalone wcześniej wnioski. Jednak elastyczność w zakresie ilości zajęć indywidualnych przydzielanych konkretnemu dziecku dla bardzo wielu stanowi przysłowiową kość niezgody - rodzice i na- 
uczyciele chcieliby, żeby ich było jak najwięcej, upatrując w nich większych postępów edukacyjnych, zaś dyrektorzy i samorządy, którzy muszą zapewnić określone środki finansowe - by było ich jak najmniej. Niektóre samorządy usiłowały nawet odgórnie ustalić maksymalną liczbę zajęć indywidualnych przyznawanych jednemu uczniowi ze specjalnymi potrzebami edukacyjnymi na, np. nie więcej niż pięć w tygodniu, ale jest to sprzeczne z przyjętymi założeniami udzielanej pomocy, która ma przecież być dostosowana do faktycznych potrzeb danego ucznia. Inną trudność stanowi zresztą ustalenie, dla których uczniów organizacja zajęć indywidualnych w wyniku ich wyłączania lub obejmowania zindywidualizowaną ścieżką, jest faktycznie zasadna.

Do poradni psychologiczno-pedagogicznych i do dyrektorów szkół zgłaszają się rodzice, którzy wnioskują o przydzielenie dla ich syna czy córki, indywidualnych zajęć, jako argumenty podając, między innymi: uzyskiwanie przez dzieci słabych ocen szkolnych, niewystarczające przygotowanie dziecka przez szkołę do zdawania egzaminu zewnętrznego (sprawdzianu na zakończenie szkoły podstawowej, egzaminu gimnazjalnego, matury), wynoszenie niewielu wiadomości z lekcji, skargi nauczycieli na zachowanie dziecka podczas zajęć lekcyjnych, w tym jego trudności ze skupieniem uwagi, rozmowy z kolegami, nie wykonywanie poleceń i inne. Nierzadko odmowa przyznania danemu uczniowi zajęć indywidualnych związana jest $\mathrm{z}$ koniecznością przeprowadzenia obserwacji jego funkcjonowania podczas zajęć lekcyjnych, co z kolei pozwala zauważyć, że lekcje wcale nie są prowadzone metodami aktywizującymi, tylko ograniczają się do wykorzystywania książki i zeszytu, że najczęściej stosowaną jest metoda podająca, że nauczyciel zajmuje miejsce przy własnym biurku lub pod tablicą i że są, mówiąc kolokwialnie, zwyczajnie nudne - co przekłada się na nieefektywną pracę ucznia i jego małą motywację do nauki. Nauczyciele nadal mają także duże trudności w pracy z grupą zróżnicowaną, w której obok uczniów tzw. przeciętnych do jednej klasy uczęszczają uczniowie zdolni i ci z różnymi kłopotami w uczeniu się. Rozwiązaniem tych problemów nie powinno być jednak wyłączanie poszczególnych uczniów i organizowanie dla nich zajęć indywidualnych, tylko inna praca nauczycieli. I na tym też musimy się skupić w przyszłości...

Dyrektorzy szkół mają także duże problemy z samą organizacją zajęć indywidualnych na terenie szkoły, co jest związane z kilkoma czynnikami. Pierwszym jest konieczność ułożenia planu lekcji, by na konkretnej godzinie, podczas której uczeń opuszcza klasę, celem realizacji zajęć formie indywidualnej, dysponować także nauczycielem posiadającym uprawnienia do nauczania danego przedmiotu. Jest to kłopot, który najbardziej uderza w tzw. małe szkoły, gdzie jednego przedmiotu uczy tylko jeden nauczyciel i nie ma komu zlecić prowadzenia indywidualnych zajęć z danego przedmiotu o określonej. Trzeba także dysponować wolnym pomieszczeniem, w którym uczeń może swoje zajęcia indywidualne 
o danej porze zrealizować. To drugi problem, który zgłaszają dyrektorzy szkół, argumentując, że zwiększyła im się ilość oddziałów, np. w szkołach podstawowych w bieżącym roku szkolnym doszła klasa siódma, a w kolejnym roku przybędzie klasa ósma. W tej sytuacji, jeżeli w szkole jest tylko jeden lub dwóch uczniów ze specjalnymi potrzebami, którzy korzystają z zajęć indywidualnych, możliwa jest ich zorganizowanie. Jeżeli jednak takich uczniów jest wielu, a ich ilość zwiększa się jeszcze w ciągu roku szkolnego, nie można dziwić się niechęci dyrektorów do tej formy wsparcia.

A inne wątpliwości i dylematy.... Pewne niebezpieczeństwo stanowi już sama obecność dodatkowej osoby dorosłej, w tym nauczyciela z kwalifikacjami z zakresu pedagogiki specjalnej [Szumski 2010: 135-136]. Niewątpliwie dodatkowy nauczyciel wspiera pracę pojedynczego ucznia ze specjalnymi potrzebami w klasie ogólnodostępnej czy też grupy uczniów niepełnosprawnych w klasie integracyjnej, przez co ich nauka staje się z pewnością efektywniejsza. Jednak obecność dodatkowych osób dorosłych niejako przypisanych do uczniów ze specjalnymi potrzebami edukacyjnymi, czy to podczas zajęć klasowych, czy też podczas zajęć indywidualnych poza klasą, może przynosić także negatywne skutki, szczególnie $\mathrm{w}$ aspekcie ich stygmatyzacji - fakt zindywidualizowanej opieki nauczyciela przypomina pozostałym uczniom o odmienności ich rówieśnika i/lub jego nieradzeniu sobie z programem szkolnym. Także może to mieć wpływ na pogarszanie się więzi pomiędzy wszystkimi uczniami dlatego, że zmniejsza się liczba interakcji pomiędzy nimi, szczególnie w sytuacji zbyt częstego wyłączania danego ucznia w ciągu dnia z grupy klasowej - a to przecież właśnie interakcje sprzyjają redukcji uprzedzeń i kształtowaniu się pozytywnych wzajemnych nastawień [Szumski 2010: 136]. Jednak i rodzicom, i nauczycielom nierzadko wydaje się, że zabezpieczenie dla danego ucznia, np. niepełnosprawnego, dodatkowego, jego nauczyciela, wspomoże lub w ogóle umożliwi edukację w szkole ogólnodostępnej6. Stąd niejako wymuszanie na diagnostach $\mathrm{w}$ poradniach psychologiczno-pedagogicznych i na członkach zespołów orzekających, by na druku orzeczenia o potrzebie kształcenia specjalnego ustalona była tzw. niepełnosprawność sprzężona. Sprzężenie jednej niepełnosprawności z inną od razu w sposób istotny podnosi wagę przeliczeniową (patrz wyżej) sprawiając, że subwencja i dotacja na takiego ucznia istotnie się zwiększa i powoduje, szczególnie w szkołach i placówkach niepublicznych, że opłaca się zatrudnić pedagoga specjalnego jako dodatkowego nauczycie-

6 Problem ten dotyczy szczególnie uczniów z niepełnosprawnościami intelektualnymi w stopniu umiarkowanym i znacznym, dla których realizowane treści przedmiotowe w klasie ogólnodostępnej są za trudne, niezrozumiałe, a sam pobyt ucznia przez cały dzień w szkole ogólnodostępnej nic pozytywnego dla jego rozwoju nie wnosi, gdyż, między innymi, nie pozwala mu na zaspokajanie jego podstawowych ogólnoludzkich potrzeb, w tym: sukcesu, przyjaźni, rozwijania zainteresowań. Rodzice jednak nie chcą brać pod uwagę nauki ich dziecka w szkole czy placówce specjalnej, która, zadaniem specjalistów, byłaby zasadniejsza. 
la. Tym sposobem uczeń włączony jest $\mathrm{w}$ grupę pełnosprawnych rówieśników, pozostając jednak pod indywidualną opieką swojego nauczyciela, który, jak wynika z praktyki, przejmuje nad nim całkowita opiekę i odpowiedzialność, nie tylko ucząc go i siedząc z nim w jednej szkolnej ławce, ale także spędzając z nim przerwy (szczególnie w klasach starszych). Taka sytuacja często dotyczy dzieci i młodzieży z zespołem Downa, gdzie oprócz niepełnosprawności intelektualnej rodzice przynoszą od lekarzy dokumentację świadczącą o współwystępującej niepełnosprawności ruchowej, czy z innymi schorzeniami genetycznymi, gdzie, $\mathrm{w}$ przypadku np. noszenia okularów, uzasadniają konieczność zaliczenia ich dziecka do grupy osób słabowidzących. Miejmy nadzieję, że wdrażana w życie Międzynarodowa Klasyfikacja Funkcjonowania Niepełnosprawności i Zdrowia, nastawiona nie tylko na ustalenie rodzaju niepełnosprawności, ale także odnosząca się do możliwości bycia osobą aktywną i uczestniczącą w środowisku [Światowa Organizacja Zdrowia 2009], spowoduje odejście od ww. wag finansowania uczniów i związanych z tym doszukiwaniem się dodatkowych niesprawności u dzieci. Tym samym umożliwi pozyskiwanie dodatkowego nauczyciela pedagoga specjalnego w sytuacjach, gdy zaistnieje faktycznie taka potrzeba.

W szkole inkluzyjnej istnieje ponadto możliwość wystąpienia zjawiska zwanego dystansem społecznym, ujawniającym się brakiem umiejętności współdziałania i zaburzonymi relacjami społecznymi oraz traktowaniem niektórych uczniów w kategorii Innych/Obcych [Gajdzica 2011: 2004-2006]. Nadużywanie formy wspierania uczniów ze specjalnymi potrzebami edukacyjnymi przez ich wyłączanie z zajęć lekcyjnych może prowadzić do doświadczania przez nich jeszcze większego poczucia inności w stosunku do rówieśników o niezaburzonym rozwoju, którzy dobrze funkcjonują w strukturze szkolnej i nie mają większych problemów z nauką. A przecież: „Podstawą niwelowania relacji opartych na schemacie my inni jest wspólne działanie. Podejmowanie czynności ukierunkowanych na realizację tożsamych celów, przy założeniu współdziałania, sprzyja nawiązywaniu interakcji. Przydzielanie określonych funkcji/zadań, których spełnienie (wykonywanie) prowadzi do intensyfikacji kontaktów wszystkich uczestników interakcji jest jednym z możliwych rozwiązań niwelowania dystansu" [Gajdzica 2011: 2006]. Jednym z celów edukacji inkluzyjnej jest zmniejszanie dystansu pomiędzy wszystkimi uczniami w jednej szkole, należy więc szczególnie uważać, by jednocześnie, poprzez wyłączanie, tego dystansu nie zwiększać. Owo wyłączanie to jedna $\mathrm{z}$ form wspierania uczniów ze specjalnymi potrzebami edukacyjnymi, powinno być wykorzystywane tylko w szczególnych wypadkach i stanowić określoną w czasie drogę do celu, jakim jest możliwość uczestniczenia wszystkich uczniów we wspólnym nurcie edukacji w jak największym wymiarze. 


\section{Bibliografia}

Europejska Agencja ds. Specjalnych Potrzeb i Edukacji Włączającej (2014), Pięć kluczowych przestań dla edukacji włączającej. Od teorii do praktyki, Odense, Dania.

Gajdzica Z. (2011), Sytuacje trudne w opinii nauczycieli klas integracyjnych, Oficyna Wydawnicza „Impuls”, Kraków.

Gołubiew-Konieczna M (2015), W poszukiwaniu optymalnych modeli kształcenia uczniów niepetnosprawnych w myśl art. 24 Konwencji o prawach osób niepetnosprawnych $i$ obowiązujących przepisów prawa oświatowego, „Niepełnosprawność. Dyskursy pedagogiki specjalnej” nr 20.

Konwencja o prawach osób niepetnosprawnych - www.rpo.gov.pl [dostęp: 25.05.2018].

Kosakowski Cz. (2001), Nauczanie i wychowanie osób lekko upośledzonych umystowo, Wydawnictwo Edukacyjne Akapit, Torun.

Kowalik S. (2011), Integracja uczniów niepetnosprawnych z uczniami petnosprawnymi [w:] Wspomaganie rozwoju, psychostymulacja i psychokorekcja, t. 3, B. Kaja (red.), Wydswnictwo Akademia Bydgoska, Bydgoszcz.

Kubicki P. (2017), Finansowanie kształcenia specjalnego i pomocy psychologiczno-pedagogicznej, materiał opracowany dla ekspertów MEN ds. opracowywania modelu kształcenia włączającego uczniów ze specjalnymi potrzebami edukacyjnymi (nieopublikowany).

Speck O. (2013), Inkluzja edukacyjna a pedagogika lecznicza, Wydawnictwo Harmonia, Gdańsk.

Speck O. (2015), Osoby z niepetnosprawnościa intelektualną. Podręcznik dla celów wychowawczych i edukacyjnych, Wydawnictwo Harmonia, Gdańsk.

Szumski G. (2010), Wokót edukacji włączającej. Efekty kształcenia uczniów z niepetnosprawnościq intelektualna w stopniu lekkim w klasach specjalnych, integracyjnych i ogólnodostępnych, Wydawnictwo APS, Warszawa.

Światowa Organizacja Zdrowia (2009), ICF - Międzynarodowa Klasyfikacja Funkcjonowania, Niepetnosprawności i Zdrowia, Wydawnictwo CSIOZ, Warszawa.

Zespół MEN (2010), Jak organizować edukację uczniów ze specjalnymi potrzebami edukacyjnymi, Warszawa.

Zespół ORE (2015), Dziecko z niepetnosprawnościa w przedszkolu i szkole ogólnodostępnej - wyzwania dla JST, Warszawa.

\section{Obowiązujące akty prawne:}

Ustawa Prawo Oświatowe z dnia 14 grudnia 2016 r. (Dz. U. z 2017 r., poz. 59).

Rozporządzenie MEN z dnia 9 sierpnia 2017 r. w sprawie warunków organizowania kształcenia, wychowania i opieki dla dzieci i młodzieży niepełnosprawnych, niedostosowanych społecznie i zagrożonych niedostosowaniem społecznym (Dz. U. z 2017 r., poz. 1578).

Rozporządzenie MEN z dnia 9 sierpnia 2017 r. w sprawie zasad organizacji i udzielania pomocy psychologiczno-pedagogicznej w publicznych przedszkolach, szkołach i placówkach (Dz. U. z 2017 r., poz. 1591).

Rozporządzenie MEN z dnia 17 marca 2017 r. w sprawie szczegółowej organizacji publicznych szkół i publicznych przedszkoli (Dz. U. z 2017 r., poz. 649 z późn. zm.). 
Rozporządzenie MEN z dnia 9 sierpnia 2017 r. w sprawie indywidualnego rocznego obowiązkowego przygotowania przedszkolnego dzieci oraz indywidualnego nauczania dzieci i młodzieży (Dz. U. z 2017 r., poz. 1616).

Rozporządzeniu z dnia 7 września 2017 r. w sprawie orzeczeń i opinii wydawanych przez zespoły orzekające działające $\mathrm{w}$ publicznych poradniach psychologiczno-pedagogicznych (Dz. U. z 2017 r., poz. 1743).

Rozporządzenie MEN z dnia 14 lutego 2017 r. w sprawie podstawy programowej wychowania przedszkolnego oraz podstawy programowej kształcenia ogólnego dla szkoły podstawowej, w tym dla uczniów z niepełnosprawnością intelektualną w stopniu umiarkowanym lub znacznym, kształcenia ogólnego dla branżowej szkoły I stopnia, kształcenia ogólnego dla szkoły specjalnej przysposabiającej do pracy oraz kształcenia ogólnego dla szkoły policealnej (Dz. U. z 2017 r., poz. 356).

Rozporządzenie MEN z dnie 15 grudnia 2018 r. w sprawie sposobu podziału części oświatowej subwencji ogólnej dla jednostek samorządu terytorialnego w 2018 r. (Dz. U. z 2017 r., poz. 2395). 